\title{
U.S. Policymaking to Address Menstruation: Advancing an Equity Agenda
}

\author{
Jennifer Weiss-Wolf
}

In the United States, mainstream acknowledgment of menstruation as a source of struggle - in the media and among policymakers-is a relatively recent phenomenon (Zraick 2018). As with most hardship, marginalized populations, including those who are poor, incarcerated, and homeless, are at greatest risk. For instance, a 2019 study found that nearly two-thirds of women surveyed in St. Louis, Missouri could not afford menstrual products during the previous year and nearly one in five could not afford them each month (Sebert Kuhlmann et al. 2019). Those experiencing homelessness report using tampons and pads for longer than recommended or improvising with items such as paper bags or newspapers (Upadhye 2016). And incarcerated individuals and those caught in the criminal justice system must often beg or bargain with corrections staff for basic hygiene needs, part of a degrading and dehumanizing power imbalance - and a failure of the state to provide for those in its custody (Bozelko 2015).

Decades of menstrual activism have laid the groundwork for the recent popular engagement (see Bobel 2008). This newest wave includes a new policy frame that colleagues and I introduced in 2015 intended to put menstruation at the heart of U.S. politics, with arguments rooted in core concepts of equity and civic participation. The deliberate choice of the phrase 'menstrual equity' as a frame harkens to the democratic creed and aspiration of civic, economic, and political engagement and opportunity in the United States. It is broader than a sanitation, hygiene or public health frame, and

Jennifer Weiss-Wolf gratefully acknowledges Victoria Miller for her editorial contributions and invaluable support.

(C) The Author(s) 2020

C. Bobel et al. (eds.), The Palgrave Handbook of Critical Menstruation

Studies, https://doi.org/10.1007/978-981-15-0614-7_41 
more applicable to U.S. policymaking than a human rights frame and hence provides a tangible basis for advocacy. It has proven to be a frame that has massive potential as evidenced by its recent and rapid success.

\section{U.S. LaW and Policy Agenda 2015-2018}

Forging meaningful change through law- and policy-making has distinct advantages. To start, implementation of laws is an efficient way to benefit the widest swath of the population. The laws we pass make an affirmative and deliberate statement about the values for which we stand-an especially critical ingredient in dismantling the stigma of menstruation.

Prior to initiation of the menstrual equity frame and advocacy campaign, menstruation had only been at the center of policymaking very briefly. For a short period of time in the 1990s, activists pressed Congress to consider menstruation-largely in response to a spate of deaths from Toxic Shock Syndrome caused by high-absorbency tampons (see Vostral 2018) followed by a later (unrelated) report by the Food and Drug Administration (FDA) of toxicity in the synthetic fibers and chemicals used in regular tampons (Fetters 2015). In 1997, U.S. Congresswoman Carolyn Maloney introduced federal legislation that would require funds for independent research into potentially hazardous ingredients in menstrual products, as well as mandate transparency in sharing and publicizing testing results (Tampon Safety and Research Act of 1997). Her bill, the Tampon Safety and Research Act of 1997 (H.R. 2900), was unsuccessful. In 1999, she renamed it the Robin Danielson Act, in honor of a woman who died from Toxic Shock Syndrome. She continued to reintroduce the bill, most recently in 2017, but it has never advanced or succeeded in garnering broad support.

There are myriad ways in which the material dimensions of menstruation continue to be disregarded as a matter of public policy: Tampons and pads have not been designated as allowable budgetary expenses for publicly funded shelters or crisis and emergency centers; they are not provided in a consistent or fully accessible way in correction and detention facilities; menstrual products are not covered by public health and nutritional benefits programs; they are not made uniformly available in schools or workplaces; in 30 states (as of April 2020), menstrual products are not sales tax exempt; inconsistent tax classification status of menstrual products prevented them from being included in Health Savings or Flexible Spending Account allowances, a change that was finally made in the Coronavirus Aid, Relief, and Economic Securities (CARES) Act, signed by President Trump on March 27, 2020 (Weiss-Wolf 2017).

Consider how different governmental agencies acknowledge and address menstrual products - not only with a disparate, inconsistent vocabulary and recognition of purpose but always to the detriment of those who menstruate: 
- The federal government bears responsibility for approving and disclosing the ingredients in menstrual products via the FDA. The FDA designates tampons a Class II "medical device" (U.S. Food and Drug Administration 2014). The only affirmative obligations required of manufacturers are that they provide basic instructional labeling on packaging and keep records of adverse events caused by their products. Transparency in testing results is not required, nor is labeling or detailed disclosure about product ingredients on packaging.

- At the U.S. Department of Labor, the Occupational Safety and Health Administration (OSHA) mandates that employers provide all workers with safe, sanitary toilet facilities as well as products required for washing and drying (United States Department of Labor, n.d.a). Menstrual products are conspicuously excluded from the list of hygiene necessities, though addressed in meticulous detail in disposal protocols for facilities (United States Department of Labor, n.d.b).

It was not until 2015, and the ascent of arguments to eliminate the "tampon tax" - shorthand for the fight to exempt menstrual product purchases from sales tax-that the issue drew meaningful attention and action. That campaign was soon joined by targeted municipal, state, and federal advocacy to ensure that products are freely accessible via public agencies that serve those who are young, have low income, homeless, or incarcerated. I describe these initiatives below, with a focus on the variety of movement-building strategies and legal arguments that have been employed.

\section{The 'Tampon Tax' as a Strategic Entry Point FOR U.S. ADVOCACY}

The 'tampon tax' is regular sales tax or value-added tax applied to menstrual products - or, conversely, the failure of the state to exempt these products from sales tax by placing them in the category of necessity. This is not a special or additive levy, or "luxury tax" as some assume, but is regular sales tax applied to menstrual products-ranging from roughly 4-10\% depending on the state tax code. Generally, and as a matter of historical practice since sales taxes were first implemented in the United States in the 1930s, states exempt food and other items deemed necessities of life, such as medicine and prescription drugs, from sales tax.

Prior to 2015, there were five states that already exempted menstrual products, though not as a result of a concerted campaign. Another five states collect no sales tax at all and therefore do not tax these items. By 2018, a further five states had successfully eliminated the 'tampon tax.'

A year's supply of tampons and pads for a person costs in the range of $\$ 70$ to $\$ 120$, depending on where one lives, the heaviness of one's flow, and the 
ability to take advantage of cost-cutting measures. (Reusable alternatives like menstrual cups, absorbent underwear, and cloth pads often have high upfront costs but are more cost-effective over time.) All told, the expense can add up to more than $\$ 5000$ over a lifetime per person; sales tax adds several hundred dollars to this total. However, this is not the only reason why campaigns have focused on lifting this tax burden.

Advocating for removal of the 'tampon tax' is a smart strategic entry point because the arguments are straightforward for the general public, salient for the media, and manage to transcend partisan politicking. This approach challenges laws that are archaic, unfair, and discriminatory and helps inch toward a model of economic parity and gender equality. From my perspective as a menstrual activist, it accomplishes all of this-and even more: It offers a gateway for enabling people to talk and think about the wider implications of menstruation-social, economic, and otherwise-in our policymaking. As a result, numerous campaigns to address the taxation of menstrual products have long been underway around the world. Notable examples are Kenya, Canada, England, Malaysia, India, Australia, and South Africa, all countries where the equivalent of sales tax has been successfully challenged (see Patkar [Chapter 38] in this volume).

In the United States, the 'tampon tax' has offered a ripe forum for domestic policy advocacy and a chance to develop and test equity-based language for addressing the economics of menstruation. Among its most distinct characteristics in the United States, the tampon tax argument has unusually strong trans-partisan appeal. There are persuasive perspectives from all sidesleft, right, libertarian-variously focused on social justice, gender equity, tax relief, and/or limiting the scope of government reach. One unique challenge we face as activists is the federal structure of the United States. Because there is no national sales tax in the United States, but instead a multitude of municipal- and state-specific tax codes, it is difficult to organize one overarching nationwide campaign.

Despite this, in October 2015, our inaugural campaign launched with the first national petition, co-sponsored by Cosmopolitan magazine, "Stop Taxing Our Periods. Period" (Change.Org, n.d.). Our primary goal for making the petition national in focus, rather than state-by-state, was to elevate the issue with a singular call for action, and then pressure state lawmakers across the country to act simultaneously when the 2016 legislative sessions commenced. The petition sparked immediate and high-level attention by the media, policymakers, and other influential voices. The New York Times editorialized in favor of not only repealing sales tax on menstrual products but also ensuring their affordability and accessibility (Editorial Board 2016). Policy and fiscal analyses were published by The Economist (2016) and the Wall Street Journal (Larimer 2016). The American Medical Association, the largest association of physicians in the United States, issued a position statement urging states to exempt menstrual products from sales tax as sound health and medical 
practice (American Medical Association 2016). An op-ed by constitutional scholar, now dean at the University of California, Berkeley, School of Law, Erwin Chemerinsky, put forth legal criteria for abolishing the tax, rooted in the argument that it would alleviate discriminatory impact (Chemerinsky 2016). Even President Obama weighed in, reflecting that the issue's historic neglect was indicative of our nation's less-than-fully representative leadership, stating, "I suspect it's because men were making the laws when those taxes were passed" (Rhodan 2016).

Legislators responded. Between 2016 and 2018, proposals to exempt menstrual products from sales tax have been introduced or debated in 24 state legislatures (Weiss-Wolf 2017, 137). The city of Chicago was the first jurisdiction in 2016 to eliminate the tampon tax. The states of New York and Illinois unanimously passed laws in 2016 that were signed by those states' respective governors-in New York, a Democrat, in Illinois, a Republicandemonstrating that there was bipartisan commitment to the issue. In the 2017 legislative session, Florida successfully passed a tax exemption for menstrual products, also signed by a Republican governor. And in 2018, Connecticut became the next state to eliminate the tax by legislation. In the nation's capital, the Washington, DC Council exempted menstrual products from sales tax in 2016. On Election Day 2018, Nevada voters approved the first-ever ballot measure on the tampon tax. The lawmakers who proposed the measure made clear their intention that the state should not be funding its needs "on the backs of women" (Kasperkevic 2018). Given the unnecessary hurdles that have emerged in several state legislatures, some detailed below, ballot measures are an important lever for making change, and a strategy to replicate going forward.

In states where bills failed, legislative rationale has varied. In California, a bill passed in 2016, only to be vetoed by the governor on grounds of fiscal restraint; it was reintroduced in 2017 and 2018, but has been unable to advance. Utah's Hygiene Tax Act did not leave the committee (an all-male panel) in 2016 and 2017. Among the reasons for rejecting the bill were fears of a too-subjective tax code and concerns about recouping \$1 million in lost revenue (Close 2016).

And yet, legislators did not raise the prospect of making up the difference in lost revenue by taxing alternative items that could be used or purchased equally by both men and women. Nor did they demonstrate concern about non-necessity items already chosen for sales tax exemption. The variety of allowable exemptions from state to state are extraordinarily subjective-ranging from kettle corn in Iowa, to gun club memberships in Wisconsin, to Mardi Gras beads in Louisiana, to arcade game tokens and potato chips purchased from a vending machine in Utah (Weiss-Wolf 2016).

Among the handful of denouncers, Washington Post opinion writer Catherine Rampell published "The Tampon Tax Fraud" (Rampell 2016). In The Daily Beast, Samantha Allen belittled "the mainstream feminist issue 
$d u$ jour" in her essay, "The 'Tampon Tax' Outrage is Overblown" (Allen 2015 ). Both framed their opposition on the argument that menstrual products are not subject to any specific, additive tax (a common retort). Wrote Rampell: "Politicians didn't decide one day that periods were gross and therefore ought to be made more expensive." And from Allen: "It is not a state-sanctioned war on periods." These statements miss the point. Whether or not it was a question of nefarious intent (doubtful) or clueless oversight (likely), the reality is that legislators had not ever before been called upon to consider menstruation at all either in the evolution of tax code exemptions or any other legislation.

In fact, the menstrual equity agenda must be taken beyond simple sales tax reform. That the sales tax question has shone a light on the issue of the economics of menstruation - and has gotten media outlets to report and editorialize on it at all-is alone a tremendous advance and fuels our ability to develop more nuanced policy arguments.

\section{Beyond the Tampon Tax: The Case for Universal Access}

Policies need to go deeper than sales tax reform, beyond ensuring equitable access to products to delve further into the many ways stigma and silence around menstruation has a harmful impact. Making the case that menstrual products be freely available to certain target populations defines the simultaneous policy agenda that we have been advancing since 2015. Three populations - students and low-income teenagers, those dependent on public shelters (see Sebert Kuhlmann et al. 2019; see also Vora [Chapter 4] in this volume), and people who are incarcerated or in the custody of the government (see Bozelko [Chapter 5] as well as Roberts [Chapter 6] in this volume) - stand out as strategic targets for advocacy — both because the need is great and there are clear policy options for addressing them.

In 2016, the New York City Council became the first jurisdiction to unanimously pass the most comprehensive legislation of its kind in the world in the form of three laws. The first requires the city to make tampons and pads freely accessible via dispensers in bathrooms at its eight hundred public schools reaching approximately three hundred thousand students. The second law provides a budget for all shelters overseen by the Department of Homeless Services and the Department of Health and Mental Hygiene to provide free menstrual products-an estimated 2 million tampons and 3.5 million pads yearly. And finally, a third law eliminates the cap on the number of pads given to women in custody of the Department of Correction, which had previously amounted to a mere eleven thin, poor quality pads per period (NYC.gov 2016).

New York City's campaign to pass these laws was swift, highly public, and extraordinarily effective. Legislators and activists worked collaboratively and focused on obtaining mainstream media coverage-high in quality and quantity - that featured an array of compelling personal stories. This led to 
resounding public support and pressure to advance legislation. The campaign unfolded quickly, over the course of a single year, and the bills passed seamlessly with the unanimous support of City leadership. The widespread support for these policies helped to spur other cities and local jurisdictions to take similar action.

A state-by-state and federal agenda has seen similar popular support and more bipartisan buy-in throughout the following two years, covering availability of menstrual products in public schools, homeless shelters, and in detention centers. In the latter case, numerous state legislators have taken up the cause for those who are incarcerated because it is an extraordinarily popular reform. 2018 polling research by the Justice Action Network shows that $90 \%$ of voters are in favor of providing free menstrual products in prisons, with robust bipartisan support (Meng, Ferreras-Copeland, and Weiss-Wolf 2018). In one state, Arizona, social media became a powerful tool for calling out the deeply ignorant commentary made by committee members, which only fueled more public support for the reform (Held 2018).

Even a very polarized Capitol Hill has taken a stand. First, after the Dignity for Incarcerated Women Act (S. 1524) was introduced in July 2017 by four U.S. Senators, which included a prominent menstrual access provision, the Department of Justice issued a rule that tampons and pads be freely provided in all federal correctional facilities (Dignity for Incarcerated Women Act 2017). By December 2018, bipartisan prison reform legislation, the FIRST STEP Act, passed and was signed into law by President Trump. It specifically includes the provision of menstrual products at federal facilities: the first-ever federal menstrual access mandate.

Menstrual equity has one of its fiercest federal champions in U.S. Congresswoman Grace Meng (D-NY), who has developed creative interventions to ease the financial burdens of menstruation, including at shelters and crisis centers, allowing them to purchase menstrual products with FEMA grant funds (Meng 2016). The Congresswoman also introduced the first-ever federal menstrual equity legislation, the Menstrual Equity for All Act of 2017 (H.R. 972) (Menstrual Equity for All Act of 2017). She reintroduced the bill in March 2019. Both versions would require state prisons to provide menstrual products as a condition of receiving federal funding and require employers with more than 100 employees to provide menstrual products in workplace bathrooms, among other provisions.

Collectively, these legislative provisions will help make menstruation more affordable for millions. And federal activity stands to vastly elevate the politics of periods on the national and global stage.

\section{WhaT'S NEXT}

As this recent menstrual equity agenda has won public support and continues to win in legislatures, our next step must be a bold one. That is, we must elevate menstruation as an actual catalyst for how we consider all of the laws 
and policies by which we live. Menstruation provides an extraordinary lens for discerning whether these measures enable full, fair societal participation. This means going further than product accessibility and safety, which has proven a valuable entry point for getting menstruation the attention it needs and deserves, but is not the end game for a holistic menstrual agenda, or indeed agenda for gender equality. Rather, it is a first step in addressing menstrual stigma and has sparked a nationwide discussion because the 'tampon tax' and lack of access to products are visible and tangible examples of inequalities that many people can easily relate to.

However, a comprehensive menstrual equity agenda entails more than that. This agenda envisions a world where patients do not hesitate to speak with their health care providers about menstrual pain and other disorders and providers do not dismiss women's symptoms; a world where no woman is perceived as unfit or too 'emotional' to do her job while menstruating; a world where all individuals who menstruate have the proper information and agency to make decisions regarding care of their bodies; and ultimately a world where menstruation is not stigmatized.

At this stage, the challenge is to move from the tangible, visible, and easily presentable to the underlying menstrual equity challenges that are much more deeply engrained in society and accentuate gender inequalities. At the top of the possibilities to address these structural challenges are educational opportunities that expand curricula on menstruation-beyond health and hygiene to integrate relevant content in lesson in history, literature, and science. This would go a long way helping to reduce the stigma and create an equitable learning environment. The opportunities also reach into labor policies that include menstruation when tackling issues ranging from workplace safety, to paid leave (see Levitt and Barnack-Tavlaris [Chapter 43] in this volume), to addressing more sweeping gender discrimination and stereotyping. They include working with health care providers to include attention to menstruation and menstrual irregularities in standard practice. The menstrual equity lens provides us with an opportunity to spot and address inequities in all spheres of life.

Embracing a menstrual equity policy frame is a new way to at once recognize the political power and absolute normalcy of periods.

\section{REFERENCES}

Allen, Samantha. 2015. "The 'Tampon Tax' Outrage Is Overblown.” The Daily Beast, October 22. http://www.thedailybeast.com/articles/2015/10/22/the-tampontax-outrage-is-overblown.html.

American Medical Association. 2016. "AMA Adopts New Policies on Final Days of Annual Meeting.” AMA-ASSN.org, June 15. https://www.ama-assn.org/ ama-adopts-new-policies-final-day-annual-meeting.

Bobel, Chris. 2008. "From Convenience to Hazard: A Short History of the Emergence of the Menstrual Activism Movement, 1971-1992." Health Care for Women International 29 (7): 738-54. 
Bozelko, Chandra. 2015. "Prisons That Withhold Menstrual Pads Humiliate Women and Violate Basic Human Rights." The Guardian, June 12. https:// www.theguardian.com/commentisfree/2015/jun/12/prisons-menstrual-padshumiliate-women-violate-rights.

Change.Org. n.d. "Stop Taxing Our Periods!" https://www.change.org/m/ end-the-tax-on-feminine-hygiene-products-notaxontampons.

Chemerinsky, Erwin. 2016. "In Tampon Tax, a Discriminatory California Policy Lives On." Los Angeles Daily News, September 21. https://www.dailynews. com/2016/09/21/in-tampon-tax-a-discriminatory-california-policy-lives-on-erwin-chemerinsky/.

Close, Kerry. 2016. "An All-Male Committee in This State Just Voted to Keep Taxing Tampons." TIME, February 11. http://time.com/money/4217234/ tampon-tax-utah/.

"Dignity for Incarcerated Women Act (S. 1524)." https://www.congress.gov/ bill/115th-congress/senate-bill/1524/text.

Editorial Board. 2016. "End the Tampon Tax." The New York Times, February 8. https://www.nytimes.com/2016/02/08/opinion/end-the-tampon-tax.html.

Fetters, Ashley. 2015. "The Tampon: A History." The Atlantic, June 1. https://www. theatlantic.com/health/archive/2015/06/history-of-the-tampon/394334/.

“FIRST STEP Act (H.R. 5682)." 2017. https://www.congress.gov/bill/115thcongress/house-bill/5682.

Held, Amy. 2018. "Arizona Department of Corrections Changes Sanitary Pad Policy Following Backlash.” National Public Radio, February 15. https://www.npr. org/sections/thetwo-way/2018/02/15/586134335/arizona-departmentof-corrections-changes-sanitary-pad-policy-following-backlash.

Kasperkevic, Jana. 2018. “Nevada's 'Tampon Tax' Ballot Initiative Brings Up Questions about Fairness and Gender Equality." Marketplace, November 1. https://www.marketplace.org/2018/11/01/elections/nevada-s-tampon-taxballot-initiative-brings-questions-about-fairness-and.

Larimer, Sarah. 2016. "The 'Tampon Tax' Explained." Washington Post, January 8. https://www.washingtonpost.com/news/wonk/wp/2016/01/08/the-tampontax-explained/.

Meng, Grace. 2016. "Meng: FEMA to Permit Homeless Assistance Providers to Purchase Feminine Hygiene Products-Such as Tampons and Pads-with Federal Grant Funds." Press release, March 1. https://meng.house.gov/media-center/ press-releases/meng-fema-to-permit-homelessassistance-providers-to-purchase-feminine.

Meng, Grace, Julissa Ferreras-Copeland, and Jennifer Weiss-Wolf. 2018. "Women Are Finally Winning the Period Rights Fight.” Newsweek, January 25. https://www. newsweek.com/women-finally-winning-period-rights-fight-790990.

“Menstrual Equity for All Act of 2017 (H.R. 972)." https://www.congress.gov/ bill/115th-congress/house-bill/972.

NYC.gov. 2016. "Mayor de Blasio Signs Legislation Increasing Access to Feminine Hygiene Products for Students, Shelter Residents and Inmates.” NYC.gov, July 13. http://wwwl.nyc.gov/office-of-the-mayor/news/611-16/mayor-de-blasio-signslegislation-increasing-access-feminine-hygiene-products-students-.

Rampell, Catherine. 2016. "The 'Tampon Tax' Fraud." Washington Post, January 25. https://www.washingtonpost.com/opinions/the-tampon-tax-fraud/2016/01/ 25/fb9c7e68-c3a8-11e5-8965-0607e0e265ce_story.html?utm_term = . ad6a992cl126. 
Rhodan, Maya. 2016. "President Obama Doesn't Understand the 'Tampon Tax' Either." TIME, January 15. http://time.com/4183108/obama-tampon-taxsanitary/.

Sebert Kuhlmann, Anna, Eleanor Peters Bergquist, Djenie Danjoint, and L. Lewis Wall. 2019. "Unmet Menstrual Hygiene Needs among Low-Income Women." Obstetrics \& Gynecology, February. https://journals.lww.com/greenjournal/Fulltext/2019/02000/Unmet_Menstrual_Hygiene_Needs_Among_ Low_Income.2.aspx.

“Tampon Safety and Research Act of 1997 (H.R. 2900)." https://www.congress. gov/bill/105th-congress/house-bill/2900/text.

The Economist. 2016. "Removing the Tampon Tax Is Good Politics, but What about the Economics?" The Economist, March 18. https://www.economist. com/free-exchange/2016/03/18/removing-the-tampon-tax-is-good-politicsbut-what-about-the-economics.

U.S. Food and Drug Administration. 2014. "Classify Your Medical Device.” Updated July 29. https://www.fda.gov/MedicalDevices/DeviceRegulationandGuidance/ Overview/ClassifyYourDevice/default.htm.

United States Department of Labor. n.d.a. "Most Frequently Asked Questions Concerning the Bloodborne Pathogens Section." https://www.osha.gov/ laws-regs/standardinterpretations/1993-02-01-0.

_. n.d.b. "Restroom and Sanitation Requirements." https://www.osha.gov/ SLTC/restrooms_sanitation/.

Upadhye, Janet. 2016. "This Is How Homeless Women Cope with Their Periods." Bustle, October 18. https://www.bustle.com/articles/190092-this-is-how-homelesswomen-cope-with-their-periods.

Weiss-Wolf, Jennifer. 2016. "Menstrual Products Are Taxed in 40 States: Here's What You Can Buy Tax-Free.” Ms, February 19. http://msmagazine.com/ blog/2016/02/19/menstrual-products-are-taxed-in-40-states-heres-what-youcan-buy-tax-free/.

- 2017. Periods Gone Public: Taking a Stand for Menstrual Equity. New York: Arcade Publishing.

Vostral, Sharra. 2018. Toxic Shock: A Social History. New York: New York University Press.

Zraick, Karen. 2018. "It's Not Just the Tampon Tax: Why Periods Are Political." The New York Times, July 22. https://www.nytimes.com/2018/07/22/health/tampon-tax-periods-menstruation-nyt.html. 
Open Access This chapter is licensed under the terms of the Creative Commons Attribution 4.0 International License (http://creativecommons.org/licenses/ by $/ 4.0 /)$, which permits use, sharing, adaptation, distribution and reproduction in any medium or format, as long as you give appropriate credit to the original author(s) and the source, provide a link to the Creative Commons license and indicate if changes were made.

The images or other third party material in this chapter are included in the chapter's Creative Commons license, unless indicated otherwise in a credit line to the material. If material is not included in the chapter's Creative Commons license and your intended use is not permitted by statutory regulation or exceeds the permitted use, you will need to obtain permission directly from the copyright holder. 